\title{
EUROPEAN JUDICIAL SYSTEMS AS A CHALLENGE FOR DEMOCRACY
}

\author{
Edited by \\ ElżBieta KużelewsKa \\ Dariusz KLOZA \\ Izabela KRAŚNICKA \\ Franciszek STRZYCZKOWSKI
}

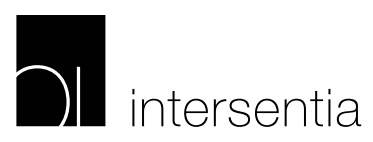

Cambridge - Antwerp - Portland 
Intersentia Ltd

Sheraton House | Castle Park

Cambridge | CB3 0AX | United Kingdom

Tel.: +44 1223370170 | Email: mail@intersentia.co.uk

Distribution for the UK:

NBN International

Airport Business Centre, 10 Thornbury Road

Plymouth, PL6 7 PP

United Kingdom

Tel.: +441752202301 | Fax: +441752202331

Email: orders@nbninternational.com

Distribution for Austria:

Neuer Wissenschaftlicher Verlag

Argentinierstraße 42/6

1040 Wien

Austria

Tel.: +431535610324

Email: office@nwv.at
Distribution for the USA and Canada: International Specialized Book Services 920 NE 58th Ave. Suite 300

Portland, OR 97213

USA

Tel.: +1 8009446190 (toll free)

Email:info@isbs.com

Distribution for other countries:

Intersentia Publishing nv

Groenstraat 31

2640 Mortsel

Belgium

Tel.: +3236801550

Email: mail@intersentia.be

European Judicial Systems as a Challenge for Democracy

Elżbieta Kużelewska, Dariusz Kloza, Izabela Kraśnicka and Franciszek Strzyczkowski (eds.)

Review: Prof. Dr. Paul De Hert, Vrije Universiteit Brussel and Tilburg University

Cover illustration: General Illustration of the Court of Justice of the European Union (c) Court of Justice of the European Union

(C) 2015 Intersentia

Cambridge - Antwerp - Portland

www.intersentia.com | www.intersentia.co.uk

ISBN 978-1-78068-316-4

D/2015/7849/90

NUR 828

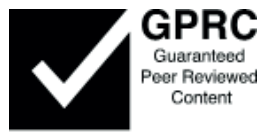

British Library Cataloguing in Publication Data. A catalogue record for this book is available from the British Library.

No part of this book may be reproduced in any form, by print, photoprint, microfilm or any other means, without written permission from the publisher. 


\section{FOREWORD}

\section{BY PROF. MACIEJ SZPUNAR, ADVOCATE GENERAL AT THE COURT OF JUSTICE OF THE EUROPEAN UNION}

The role of European Judiciary in the process of European integration cannot be overestimated. The achievements of European integration after the second world war are usually analysed from the perspective of political decisions that were made, initially, by the Founding Fathers and, subsequently, by the political leaders of the European countries. However, in the public debate we very often forget how much we owe to the two supreme jurisdictions of Europe, that is the Court of Justice of the European Union and the European Court of Human Rights.

One cannot deny that without some "revolutionary" decisions of the Court of Justice, the process of European integration would never come to the place where we are now. We would have never achieved the level of integration that, despite some shortcomings, still remains unique in comparison to all other initiatives of economic and political integration in the rest of the world. The Court of Justice takes the mission of ensuring that "law is observed" seriously and continues to assure that it is the rule of law which is at the heart of the European Union. The strength of the European Union comes essentially from the fact that it constitutes an autonomous legal order which rests on the concepts of direct effect and supremacy. These latter concepts were not only developed by, but and this must be emphasized - originated in the case law of the Court of Justice. The landmark decisions of the Court of Justice gave life to and strengthened the internal market that still remains the cornerstone and the main achievement of the European integration. One would not exaggerate by saying that political initiatives would remain "wishful thinking" if they were not supported by the historic decisions of the Court of Justice.

The contribution of the European Court of Human Rights is equally significant. It assured that the protection of human rights on our continent became effective and universal. The limits of human rights are no longer restricted to national boundaries nor exposed to the danger of national authorities abusing their discretionary competences. 
I am very happy that the group of young scholars, under the auspices of Elżbieta Kużelewska and Dariusz Kloza, has taken the initiative to explore the challenges for the European Judiciary that have emerged in recent years. It seems clear that despite its evident achievements, the process of European integration is, if not at a crossroads, at least at a moment where important choices have to be made. It is impossible to enumerate all these challenges. They stem not only from internal changes and developments of the European Union, but also from external threats.

The authors of the contributions to the book decided to concentrate their research on the response of the European Judiciary to the problems of modern democracy. The problem of the so-called democratic deficit has been present in the academic debate for many years. It has been discussed by political scientists, lawyers and economists. The continuing extension of the competences of the European Union, especially in the field economic and monetary policy, calls for the new assessment of the nature of the decision making process at the European level. Is this process sufficiently democratic? If not, what are alternative solutions? To what extent can one accept a possible shift from the traditional model of a democratic decision making process towards new models? These kinds of questions will have to be dealt with by the Court of Justice of the European Union as well as by the European Court of Human Rights. Clearly, the mere existence of judicial review does not make a decision making process democratic. It does, however, strengthen the accountability of decision making bodies. Moreover, it is for the European judiciary to shape the democratic framework of the decision making process. Will the response of the European judiciary to the new challenges be as brave and effective as in the past?

Maciej SZPUnAR Luxembourg, March 2015 


\title{
PREFACE \\ EUROPEAN INTEGRATION, DEMOCRACY AND THE COURTS
}

\author{
Toutes ces institutions pourront être modifiées et améliorées à l'expérience \\ Jean Monnet ${ }^{1}$
}

The process of European integration is "evolving and the form it finally takes still cannot be predicted". ${ }^{2}$ The European judiciary - i.e. the Court of Justice of the European Union (CJEU), the European Court of Human Rights (ECtHR) and national courts interpreting and applying European law sensu largo - have shaped this process actively, alongside the Founding Fathers, European nations, European states and their citizens. The involvement of judiciary raises its own wide range of questions concerning the very nature of democracy. Much ink has been already spilled over issues such as democratic legitimacy, subsidiarity and accountability, the rule of law or judicial activism. But it was the recently celebrated $50^{\text {th }}$ anniversaries of Van Gend en Loos (1963) ${ }^{3}$ and Costa $v$ ENEL $(1964)^{4}$ judgements that gave us further impetus to ponder about the place of the European judiciary in the democratic life in the Old Continent and their role in the process of its integration.

Therefore, under the auspices of the Centre for Direct Democracy Studies (CDDS) at the Faculty of Law, University of Białystok, in March 2014 we issued a call for papers and seventeen scholars from across Europe, predominantly young researchers, have kindly responded thereto and shared their views on the European judiciary as a challenge for democracy.

The present book constitutes the third fruit of our academic interest in the questions posed by European integration and democracy. In 2012 the Centre established a dedicated, peer-reviewed book series that produced, up-to-date, two volumes. ${ }^{5}$ It is edifying that from this volume onwards, the reputable

J. Monnet, Les États-Unis d'Europe ont commencé, Robert Laffont, Paris 1955, 141 pp.

K.-D. Borchardt, The ABC of European Union law, Publications Office of the European Union, Luxembourg 2010, p. 32.

3 Case 26/62, NV Algemene Transporten Expeditie Onderneming van Gend en Loos $v$ Nederlandse Administratie der Belastingen [1963] ECR 1.

Case 6/64, Flamino Costa $v$ ENEL [1964] ECR 585.

The two previous books were: E. Kużelewska and D. Kloza (eds.), The Challenges of Modern Democracy and European Integration, European Integration and Democracy Series, Vol. 1, 
Belgian-based international publishing house Intersentia has decided to publish this series.

The various contributions to the present volume have been split into two parts. The first provides ten chapters on the judicial systems of the European Union (EU), discussing, inter alia, recognition of democratic principles in the case law of the CJEU, contribution thereof to the democratisation of the Union and reception of EU law in the Member States. The second part discusses the judicial means to protect human rights in Europe, consisting of three chapters devoted to the promise of advisory opinions of ECtHR as well as to democratic standards for voting and for fair trial.

The authors of this collection of papers have done an excellent and outstanding job illuminating - as Advocate General Maciej Szupnar, who kindly provided this book with a foreword, puts it - "the response of the European judiciary to the problems of modern democracy". The series editors, the reviewers and the peer-reviewers helped us ensuring academic quality of this volume. We have been fortunate to work with Intersentia and our editor Tom Scheirs. Further invaluable assistance was received from Michał Czerniawski, Valentin Gros, Władysław Jóźwicki and Monika Kokštaitè. We thank them all. Finally, each of us, editors, undersigned, thank each other for this piece of teamwork.

We gratefully acknowledge financial and intellectual support of the Faculty of Law, University of Białystok, the Faculty of Law and Administration, University of Łódź as well as of the Institute for European Studies, Vrije Universiteit Brussel.

The corresponding editors welcome any comments and suggestions at ekuzelewska@gmail.com and dariusz.kloza@interia.pl, respectively.

Elżbieta KużELEWSKA

Dariusz KLOZA

Izabela KRAŚNICKA

Franciszek STRZYCZKOWSKI

Białystok - Łódź - Brussels, March 2015

Aspra-JR: Warsaw-Białystok 2012, 249 pp.; E. Kużelewska and D. Kloza (eds.), Elections to the European Parliament as a Challenge for Democracy, European Integration and Democracy Series, Vol. 2, Aspra-JR: Warsaw-Białystok 2013, 371 pp. 


\section{CONTENTS}

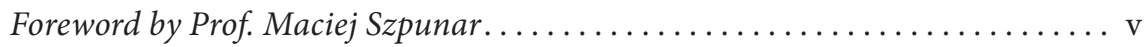



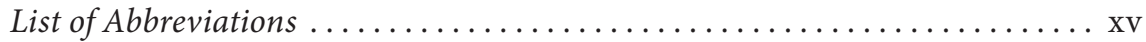

PART ONE

THE COURT OF JUSTICE OF THE EUROPEAN UNION

1. Democracy in Constitutional Politics of European Courts:

An Overview of Selected Issues

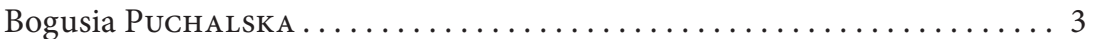

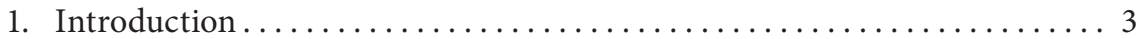

2. The ECJ and national courts: power struggle or cooperation? .......6 6

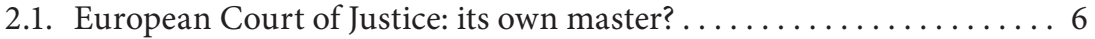

2.2. The main tenets of ECJ's constitutional politics $\ldots \ldots \ldots \ldots \ldots \ldots 7$

2.3. The enduring attraction of the concept of sovereignty in relations between the ECJ and NCs . . . . . . . . . . . . . . . . 10

2.4. Beyond 'sovereignty': power struggle, or power-posturing? . . . . 14

3. The supremacy of EU economic policy ................... 16

3.1. What is the model of economic policy entrenched in the Treaties? . . 17

3.2. The ECJ and the EU's 'democratic deficit' ............... 18

3.3. Entrenchment of the EU economic policy, TTIP, and the role of

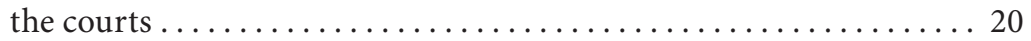

3.3.1. Democratic deficit of economic policy and the courts...... 20

a. Investor-state dispute settlement............. 21

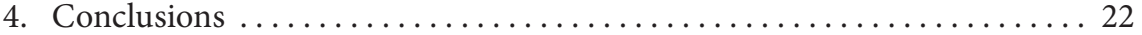

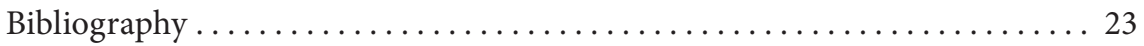

2. The Institutional Balance as CJEU's Contribution to Democracy in the Union: Selected Issues

Tomasz Dubowski ............................... 25

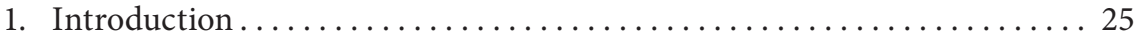

2. The CJEU and the traces of institutional balance in the Treaties ....... 26

3. Institutional balance as a general principle of EU (EC) law? The Court's role . . . . . . . . . . . . . . . . . . . . . . . . . . . . . . . . 29 
4. Institutional balance and democracy in the EU - visible links . . . . . . 32

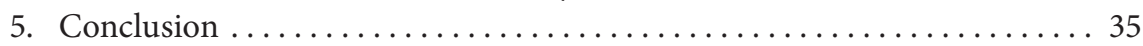

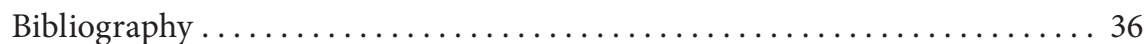

3. From Judicial Dialogue Towards Constitutional Spill-Over?

The Economic Analysis of Preliminary Reference Procedure and

the Application of the EU Charter of Fundamental Rights

Mariusz J. Golecki. . . . . . . . . . . . . . . . . . . . . . . . . . 37

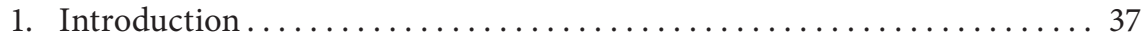

2. Constitutional courts and the preliminary reference procedure: judicial dialogue and judicial spill-over. .................. 41

3. Towards an economic analysis of breach of the EU Charter of Fundamental Rights by the national constitutional court . . . . . . . . 45

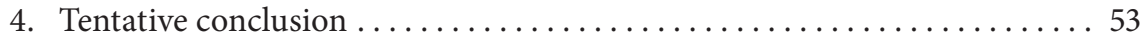

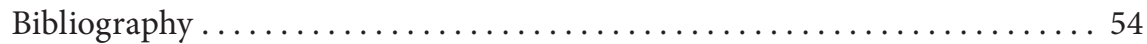

4. Towards the Democratization of the EU? Strengthening prerogatives of the European Parliament in the case law of the Court of Justice of the European Union

Agnieszka Piekutowsкa............................ 57

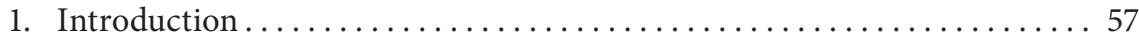

2. The defence of the prerogatives of the European Parliament before the CJEU. Pre-Lisbon case-law. . . . . . . . . . . . . . . . . . . . . . . 59

3. Post-Lisbon judgments of the CJEU on the EP's prerogatives . . . . . . 63

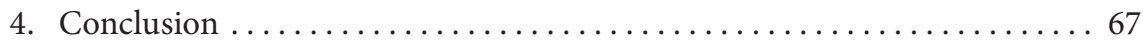

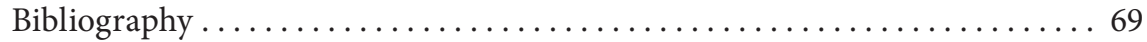

5. Democratic Values in the Court of Justice Adjudication on the Private Enforcement of the European Union Competition Law

Franciszek StrzyczKowski. . . . . . . . . . . . . . . . . 73

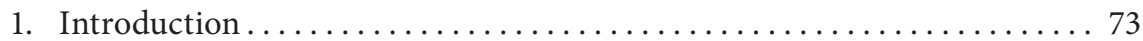

2. The influence of the American experience on private enforcement

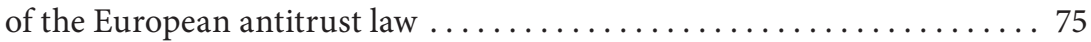

3. The importance of the reform of the EU competition law enforcement. . . 76

3.1. Towards fostering private damages actions - proposals of

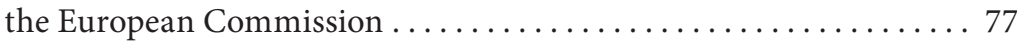

4. The position of the European Courts . . . . . . . . . . . . . 78

5. Locus standi to claim damages under European Union competition law . 83

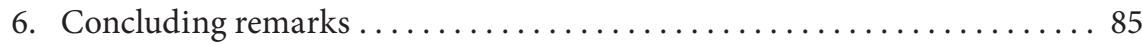

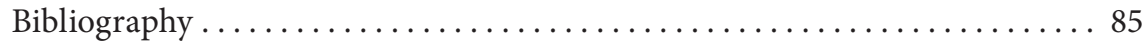




\section{Judicial Control of Monetary and Fiscal Decisions in the European Union}

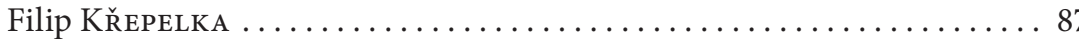

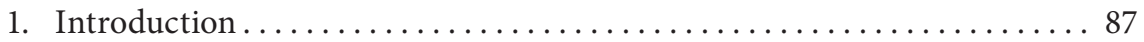

2. Traditional and emerging roles of judiciary $\ldots \ldots \ldots \ldots \ldots \ldots \ldots$

3. Rules and institutions for monetary and fiscal policy . . . . . . . . . 90

4. A single currency for the integration in the European Union . . . . . . . . . 94

5. Original legal framework for the euro . . . . . . . . . . . . . 95

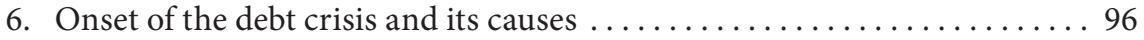

7. Alleviation of the crisis and prevention of its escalation. .......... 98

8. Political consequences of the crisis....................... 100

9. Legal aspects of remedies and reinterpretation of rules . . . . . . . . . 102

10. Judicial involvement in the crisis . . . . . . . . . . . . . . . . . . 104

11. Conclusions ...................................... 108

Bibliography ...................................... 109

7. How CJEU's “Privacy Spring” Construed the Human Rights Shield in the Digital Age

Gabriela ZANFIR ................................ 111

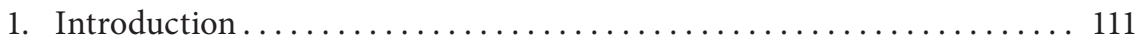

2. The relationship between individuals and the state in the digital world: Digital Rights Ireland . . . . . . . . . . . . . . . . . . 112

2.1. Preliminary observation: there is a wide societal interest

in protecting human rights against the bulk collection and retention of metadata . . . . . . . . . . . . . . . . . . . . . . . 113

2.2. Bulk retention of metadata touches on the freedom of expression,

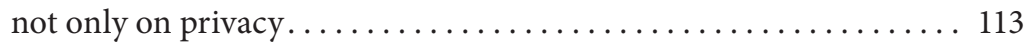

2.3. Clarification on the differences in content between Articles 7 and 8 of the Charter ................................. 115

2.4. Requirements for data retention legislation to comply with fundamental rights.

3. The relationship between individuals and private bodies in the digital world: Google v. Spain

3.1. Internet search engines are data controllers and their activity involves processing of personal data . . . . . . . . . . . . . 120

3.2. "Global" territorial scope of Directive 95/46/EC . . . . . . . . . . . 121

3.3. The right to erasure applies when the processing does not comply with the provisions of Directive 95/46/EC . . . . . . . . . . 122

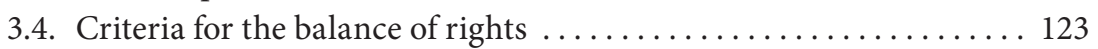

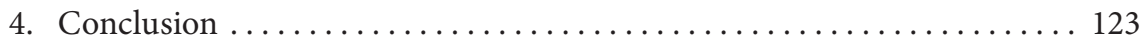

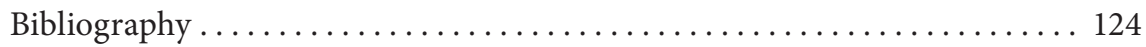


8. The Supremacy of the EU Law as Interpreted by the Polish Constitutional Tribunal

Elżbieta KużELEwsKa and Dariusz KuŻELEWSKI

1. Introduction . . . . . . . . . . . . . . . . . . . . . . . . . . . . . . . 127

2. Specificity of the constitutional review in Poland $\ldots \ldots \ldots \ldots \ldots \ldots \ldots$

3. The primacy of the EU law over national law . . . . . . . . . . . . . . 129

4. The principle of supremacy in the light of the Polish Constitutional Tribunal's judicature . . . . . . . . . . . . . . . . . . . . . . . . . . 131

5. Conclusions ..................................... 137

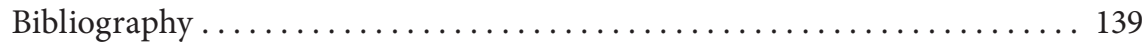

9. Reception of EU Law in Polish Courts - A Case of “Teddy Bear" Law Izabela KRAŚNICKA . . . . . . . . . . . . . . . . . . . . . . . . . . . . . . 143

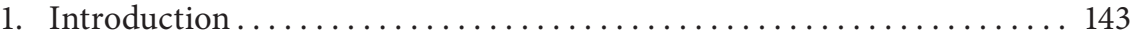

2. The principle of supremacy, the principle of direct effect and the principle of indirect effect of EU law . . . . . . . . . . . . . 144

3. "Working time" under the Polish law and EU law. . . . . . . . . . . . . . . 148

4. Czesław Miś' arguments in the light of the ECJ case law . . . . . . . . 150

5. Arguments of the Polish courts. ...................... 152

6. The final decision and its consequences.................... 154

7. Closing remarks.................................. 156

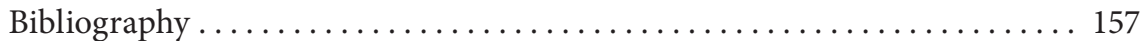

10. Enforcing Europe's Foundational Values in Central and Eastern Europe: A Case in Point

Tine Carmeliet and Georgia Christina Kosmidou. . . . . . . . . . . . . . . . . 159

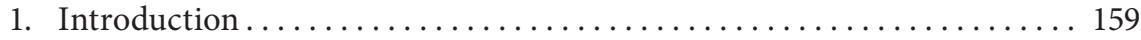

2. Shortcomings of the EU's institutional framework ............. 162

2.1. Article 7 TEU. . . . . . . . . . . . . . . . . . . . . . . . . . . 162

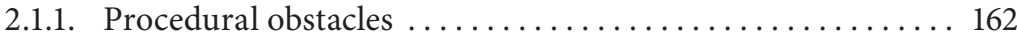

2.1.2. Substantive obstacles . . . . . . . . . . . . . . . . . . . . . . . . . 164



2.2. Legal creativity to protect the European foundational values. . . . . 167

2.2.1. Infringement actions by the European Commission . . . . . . 167

2.2.2. Social pressure and issue linkage............... 169

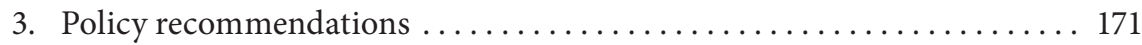

3.1. In search for a definition of liberal democracy $\ldots \ldots \ldots \ldots \ldots \ldots 17$

3.2. A stronger role for the CJEU . . . . . . . . . . . . . . . . . . 173

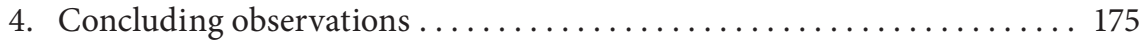

Bibliography . . . . . . . . . . . . . . . . . . . . . . . . . . . . . . . . 177 


\section{PART TWO}

\section{THE EUROPEAN COURT OF HUMAN RIGHTS}

11. Protocol 16 to the ECHR: A Convenient Tool for Judicial Dialogue and Better Domestic Implementation of the Convention?

Władysław Jóźwicki. . . . . . . . . . . . . . . . . . . . . . . . . 183

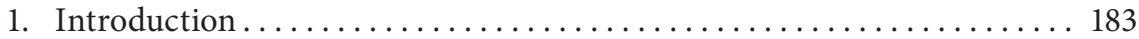

2. Protocol 16 - background $\ldots \ldots \ldots \ldots \ldots \ldots \ldots \ldots \ldots \ldots \ldots \ldots \ldots \ldots \ldots$

3. The new advisory opinion mechanism - basic characteristics. . . . . . . 187

3. Protocol 16 and the chances it opens ................... 191

3.1. A step towards enhancing domestic implementation of the ECHR. 192

3.2. A step towards more harmonious and up-to-date interpretation of the Convention . . . . . . . . . . . . . . . . . . . . . . . . . . . 193

4. Protocol 16 and its drawbacks . . . . . . . . . . . . . . . . . . . . . . . 197

4.1. ECtHR - victim of its success revisited? . . . . . . . . . . . 197

4.2. The optional and nonbinding character of the AOs and some practical concerns............................... 199

4.3. Protocol 16 and the EU ............................. 201

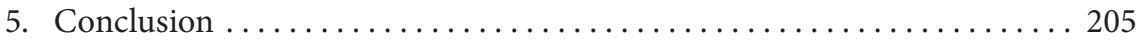

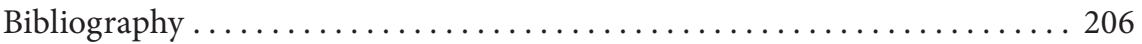

12. The EU's Parliamentary Representation in the Light of the Strasbourg Court's Sejdić and Zornić Standards: Is there Tendency for a New Parliamentary Order in the EU?

Fisnik Korenica and Dren Dolı . . . . . . . . . . . . . . . . 211

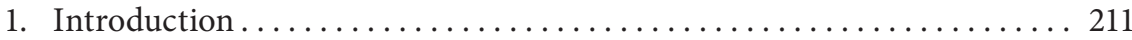

2. EU's constitutional architecture with regard to parliamentary

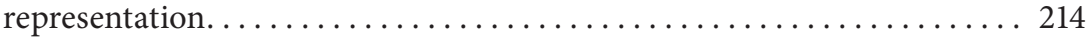

3. A note on the concept of parliamentary representation in the light of Sejdić and Zornić: European Parliament of the EU people or European Parliament of the EU Member States peoples . . . . . . . . . . . . . . . . 217

4. Thresholds on EU Parliament and 'regressive proportionality' model of electoral system: is there an objective system of electoral criteria? . . . 225

5. Concluding remarks and a general forthcoming outlook. ......... 229

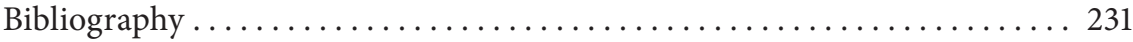


13. The European Concept of a Fair Trial and the Legal Admissibility of Assessors in the Polish Judicial System

Karol PaCHNiK and Jakub KRAJEwski.

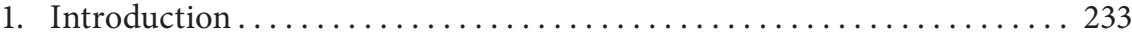

2. The position of an assessor in Polish common courts........... 233



4. Amending the organisation of courts ..................... 239

5. Regulations on assessors in Polish administrative courts - possible solutions ....................................... 241

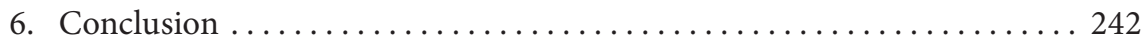

Bibliography ..................................... 243 


\section{LIST OF ABBREVIATIONS}

\begin{tabular}{|c|c|}
\hline AG & Advocate General \\
\hline $\mathrm{AO}$ & Advisory Opinion [ECtHR] \\
\hline BVerfG, FCCG & $\begin{array}{l}\text { Federal Constitutional Court [Germany] } \\
\text { (Bundesverfassungsgericht) }\end{array}$ \\
\hline $\mathrm{CC}$ & Constitutional Court \\
\hline CCP & Code of Criminal Procedure [Poland] \\
\hline CE & Central Europe \\
\hline CFR & Charter of Fundamental Rights of the European Union \\
\hline CFSP & Common Foreign and Security Policy \\
\hline CJEU & Court of Justice of the European Union \\
\hline $\mathrm{CoE}$ & Council of Europe \\
\hline CoM & Committee of Ministers [CoE] \\
\hline EAW & European Arrest Warrant \\
\hline $\mathrm{EC}$ & European Community \\
\hline EC, Commission & European Commission \\
\hline $\mathrm{ECB}$ & European Central Bank \\
\hline $\mathrm{ECHR}$ & European Convention on Human Rights \\
\hline ECJ & European Court of Justice \\
\hline ECtHR & European Court of Human Rights \\
\hline EEC & European Economic Community \\
\hline EFSF & European Financial Stability Facility \\
\hline EFSM & European Fiscal Stabilisation Mechanism \\
\hline ELA & Emergency Liquidity Assistance \\
\hline EP, Parliament & European Parliament \\
\hline ESM & European Stability Mechanism \\
\hline EU & European Union \\
\hline $\mathrm{GCh}$ & Grand Chamber [ECtHR] \\
\hline GDP & Gross Domestic Product \\
\hline ISDS & Investor-State Dispute Settlement \\
\hline MEP & Member of European Parliament \\
\hline MS & Member State \\
\hline NC & National Court \\
\hline NCA & National Competition Authorities \\
\hline OMT & Outright Monetary Transactions \\
\hline SMP & Securities Markets Programme \\
\hline
\end{tabular}


SRM Single Resolution Mechanism

SSM

Single Supervision Mechanism

TEAEC, TAEC Euratom Treaty, Treaty establishing the European Atomic Energy Community

TEC Treaty establishing European Community

TECSC Treaty establishing the European Coal and Steel Community

TEEC Treaty establishing the European Economic Community

TEU Treaty on European Union

TFEU Treaty on the Functioning of the European Union

TTIP Transatlantic Trade and Investment Partnership

$\mathrm{UK}$ United Kingdom of Great Britain and Northern Ireland 